\title{
GENETIC SYNDROMES ASSOCIATED WITH RENAL CELL CARCINOMA - A REVIEW
}

\author{
Katerina Azeem*, Helena Kollarova, Dagmar Horakova, Silvie Magnuskova, Vladimir Janout
}

Department of Preventive Medicine, Faculty of Medicine and Dentistry, Palacky University Olomouc, Czech Republic

E-mail:katkaazeem@hotmail.com

Received: January 27, 2011; Accepted: April 19, 2011

Key words: Renal cell carcinom/Genetic syndrome/Review

Aims. A review of recent knowledge on heredital syndromes related to renal cell carcinoma.

Methods. Aim of this review was to summarize the recent knowledge of genetic syndromes associated with renal cell carcinoma.

Results. Summary of incidence and factors modulating risk of hereditary renal cell carcinoma development.

Conclusions. Hereditary forms of RCC are relatively rare. Their study is beneficial in many ways. In individuals at a higher risk of a hereditary syndrome, the knowledge of hereditary forms may help to significantly decrease the impact of the hereditary disease. In the general population, knowledge acquired by the study of hereditary forms of RCC may in the future contribute to both diagnosis and treatment of sporadic tumours.

\section{INTRODUCTION}

Kidney cancer belongs to 16 most frequent malignancies in the Czech Republic and globally. In 2008, a total of 265,731 persons were diagnosed with this type of cancer and 113,315 people died (IARC) (ref. ${ }^{1}$ ). And the incidence continues to rise.

Renal cell carcinoma ( $\mathrm{RCC}$ ) is not a single entity but rather a group of tumours originating from kidney epithelium $^{2}$. RCC originates from the tubular structures of the kidney and is classified into 4 main histological types. The most common type, accounting for $75 \%$ (ref. $^{3-5}$ ) of all RCC cases, is clear cell renal cell carcinoma (ccRCC).
The others are papillary (10-15\%) (ref., $\left.{ }^{4,6}\right)$, chromophobe (3-5\%) (ref. $\left.{ }^{4-6}\right)$, onkocytoma (5-9\%) (ref. $\left.{ }^{4,5}\right)$ and collecting duct (1\%) RCC (ref. $\left.{ }^{5,6}\right)$ (Table 1$)$.

\section{CHARACTERISTICS OF HEREDITARY FORMS OF RCC}

Approximately 4\% of all RCC are hereditary ${ }^{2,7}$.

Men are twice as likely as women to become affected. The incidence of sporadic forms of RCC begins to increase after 30 years of age, with cases occurring most rapidly after the age of 45 and peaking after 70 years. This

Table 1. Classification schema for kidney epithelial neoplasias.

\begin{tabular}{|l|l|l|l|l|}
\hline Histological type & Cell origin & Genes implicated & $\begin{array}{l}\text { Chromozomal } \\
\text { abnormalities }\end{array}$ & $\begin{array}{l}\% \text { of all RCC tumors } \\
\left(\text { ref. }^{4-6}\right)\end{array}$ \\
\hline Clear cell RCC & Proximal tubule & VHL, BHD & $\begin{array}{l}-3 \mathrm{p},+5 \mathrm{q},-\mathrm{Y},-9 \mathrm{p}, \\
-14 \mathrm{q}, \mathrm{t}(3 ; 5)(\mathrm{p} ; \mathrm{q})\end{array}$ & $75 \%$ \\
\hline Papillary RCC & Proximal tubule & MET, FH, HRPT2 & $\begin{array}{l}+7,+17,-\mathrm{Y},+12,+16, \\
+20 \\
\mathrm{t}(\mathrm{X} ; 1)(\mathrm{p} 11.2 ; \mathrm{q} 21.2) \\
\mathrm{t}(\mathrm{X} ; 17)(\mathrm{p} 11.2 ; \mathrm{q} 25.3)\end{array}$ & $\begin{array}{l}\text { Type } 1:<5 \% \\
\text { Type } 2:<10 \%\end{array}$ \\
\hline Chromophobe RCC & $\begin{array}{l}\text { Intercalated cell } \\
\text { Cortical collecting duct }\end{array}$ & BHD & $\begin{array}{l}-1,-2,-6,-10,-13, \\
-17,-21\end{array}$ & $3-5 \%$ \\
\hline Oncocytoma & $\begin{array}{l}\text { Intercalated cell } \\
\text { Cortical collecting duct }\end{array}$ & BHD & $\begin{array}{l}-1,-\mathrm{Y} \\
\mathrm{t}(5 ; 11)(\mathrm{q} 35 ; \mathrm{q} 13) \\
\mathrm{t}(9 ; 11)(\mathrm{p} 23 ; \mathrm{q} 13)\end{array}$ & $5-9 \%$ \\
\hline $\begin{array}{l}\text { Collecting duct } \\
\text { (Bellini's duct) RCC }\end{array}$ & $\begin{array}{l}\text { Medullary collecting } \\
\text { duct }\end{array}$ & FH & $-7 \mathrm{q} 32,-6 \mathrm{p},-8 \mathrm{p},-21 \mathrm{q}$ & $<1 \%$ \\
\hline
\end{tabular}

Adapted from Valladares-Ayerbes M, 2008 (ref. ${ }^{5}$ ) 


\begin{tabular}{|c|c|c|c|c|c|}
\hline 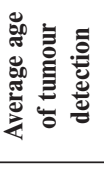 & 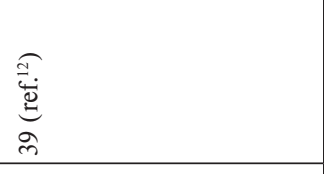 & 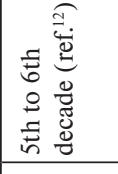 & 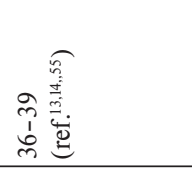 & 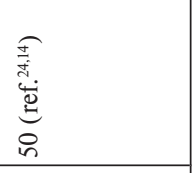 & ' \\
\hline 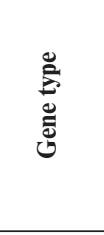 & 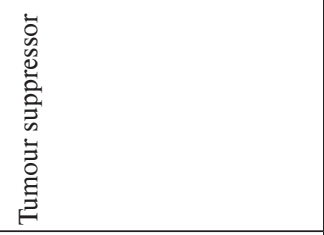 & 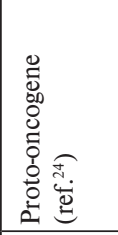 & 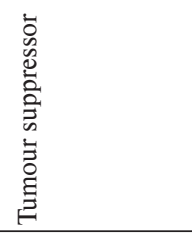 & 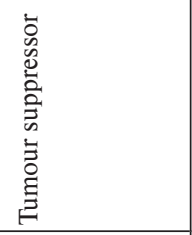 & 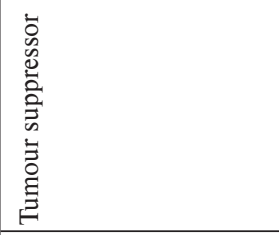 \\
\hline 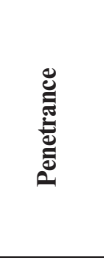 & 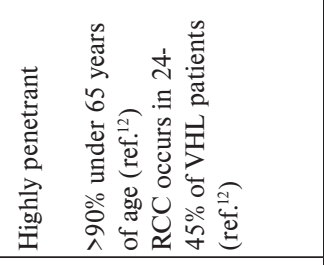 & 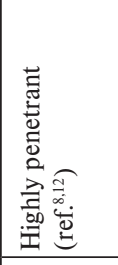 & 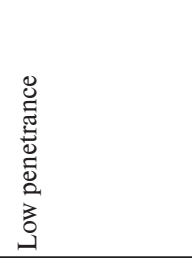 & 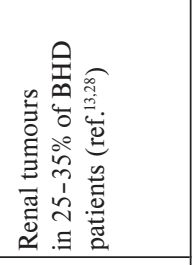 & 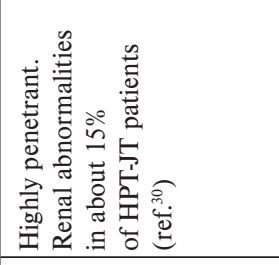 \\
\hline 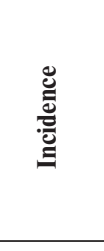 & 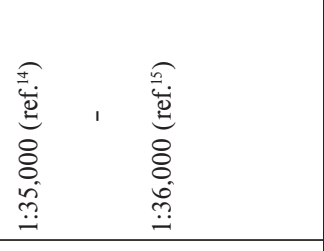 & 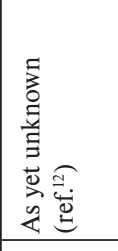 & 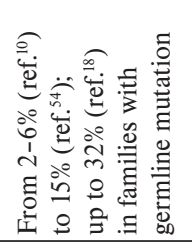 & 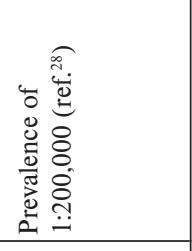 & 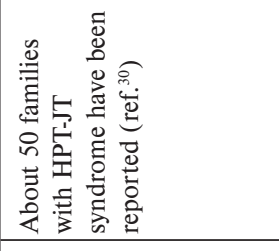 \\
\hline 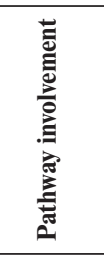 & 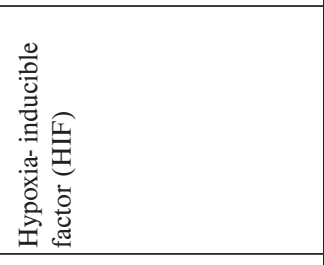 & 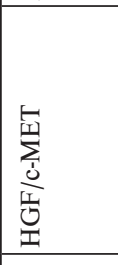 & 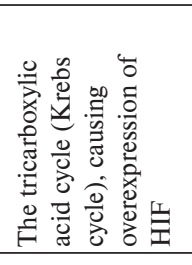 & 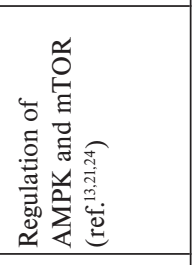 & 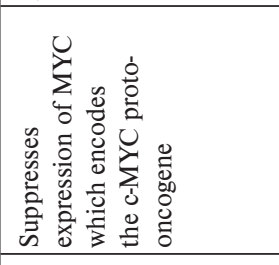 \\
\hline 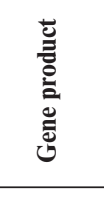 & 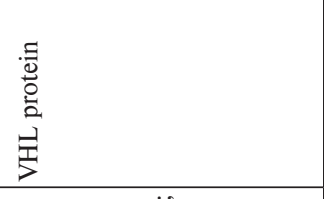 & 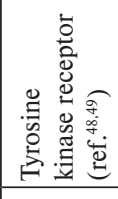 & 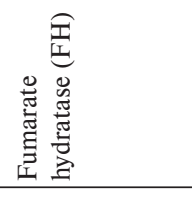 & 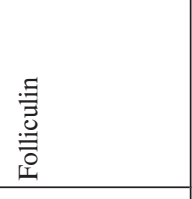 & 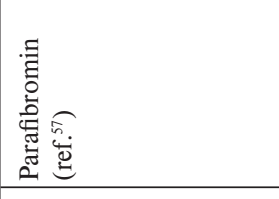 \\
\hline 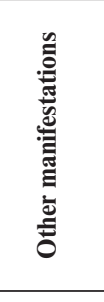 & 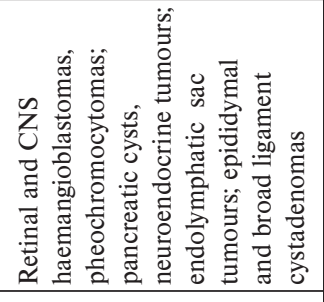 & \begin{tabular}{|l}
0 \\
$\check{\check{O}}$ \\
\end{tabular} & 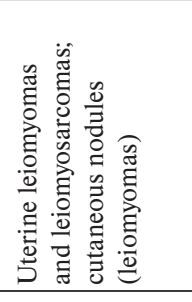 & 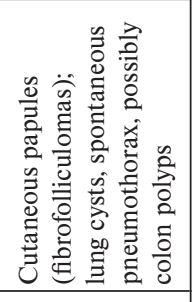 & 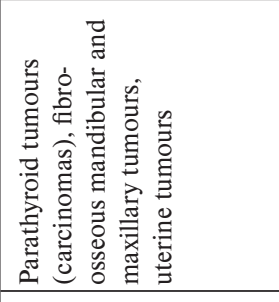 \\
\hline 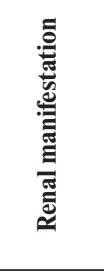 & 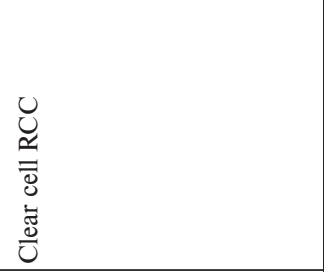 & 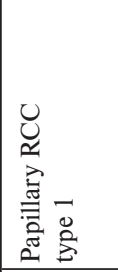 & 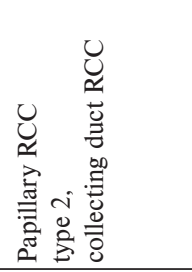 & 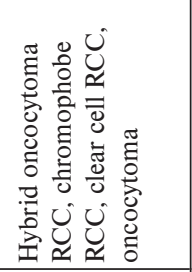 & 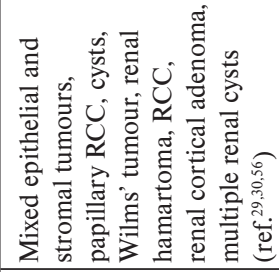 \\
\hline 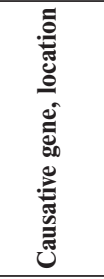 & 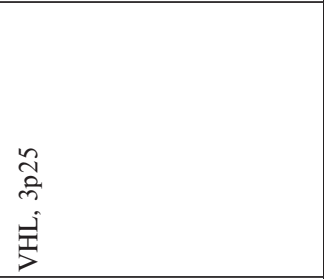 & 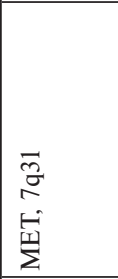 & 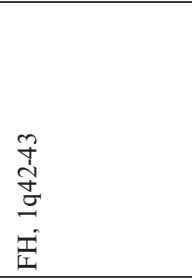 & 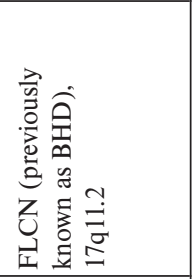 & 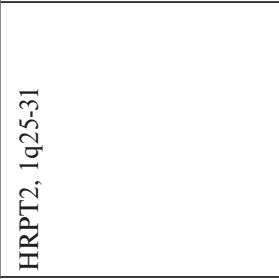 \\
\hline 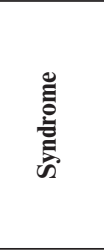 & 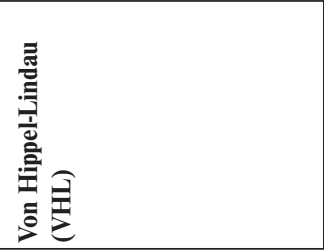 & 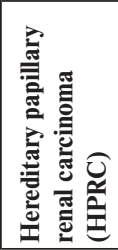 & 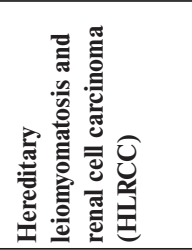 & 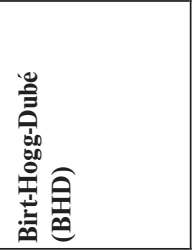 & 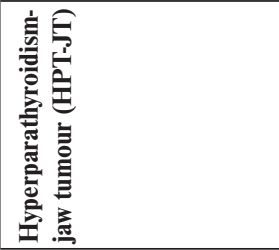 \\
\hline
\end{tabular}




\begin{tabular}{|c|c|c|c|c|c|c|}
\hline 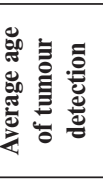 & ' & ' & 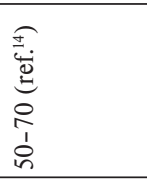 & 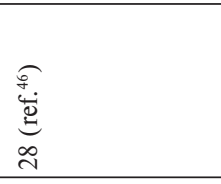 & 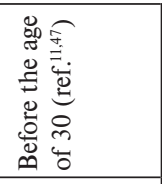 & 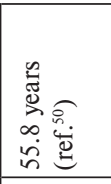 \\
\hline $\begin{array}{l}\text { D. } \\
\text { E. } \\
\text { E. } \\
\text { E. }\end{array}$ & ' & ' & I & 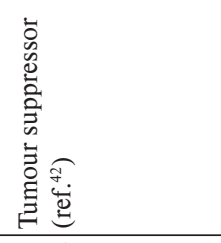 & 1 & ' \\
\hline 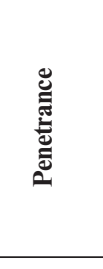 & I & ' & ב3. & 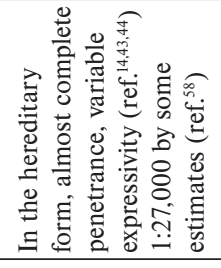 & ' & ' \\
\hline 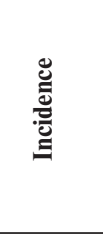 & , & ' & I & 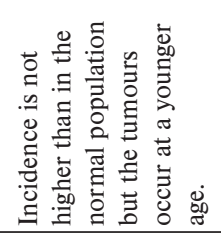 & 1 & 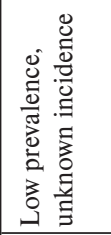 \\
\hline 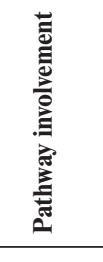 & ' & ' & ' & 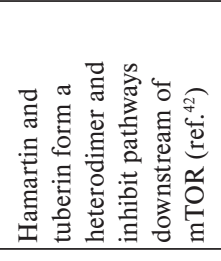 & 1 & ' \\
\hline 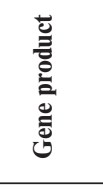 & I & ' & I & 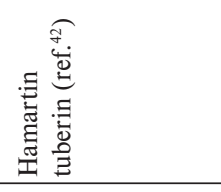 & ' & ' \\
\hline 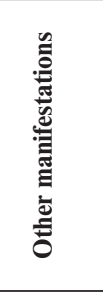 & ¿ัँ & 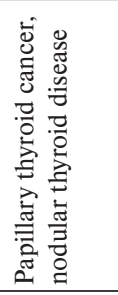 & I & 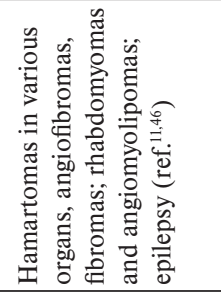 & 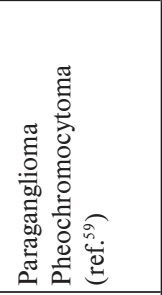 & 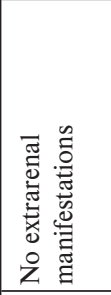 \\
\hline 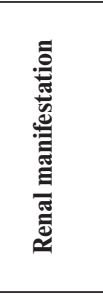 & 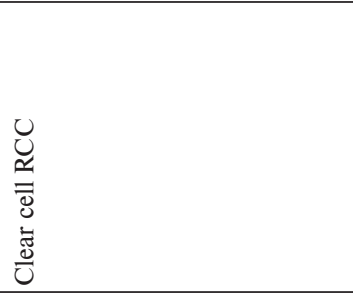 & 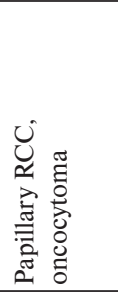 & $\begin{array}{l}\text { U } \\
\widetilde{y} \\
\end{array}$ & 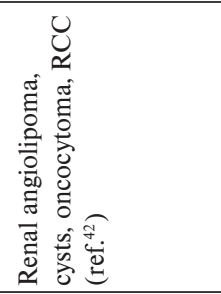 & 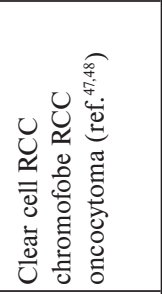 & \begin{tabular}{|l} 
\\
$\tilde{\Xi}$ \\
0 \\
0 \\
0 \\
0 \\
0 \\
\end{tabular} \\
\hline 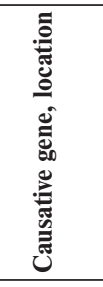 & 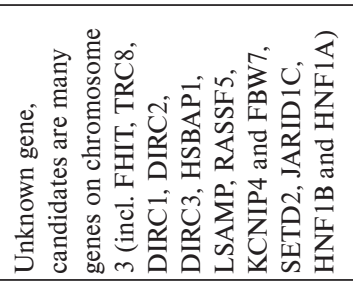 & 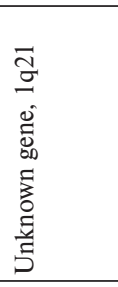 & I & 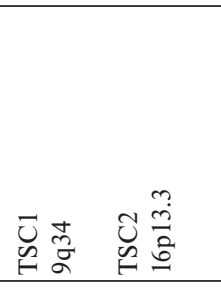 & 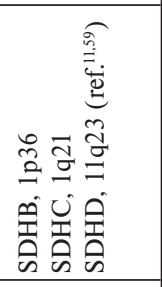 & 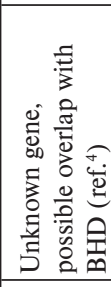 \\
\hline 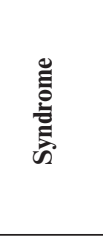 & 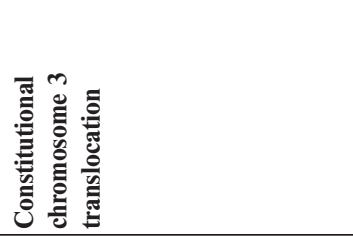 & 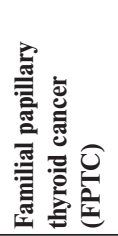 & 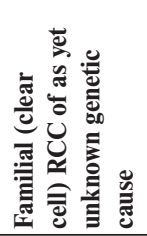 & 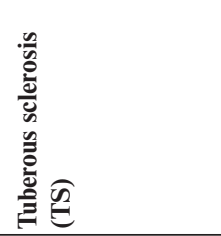 & 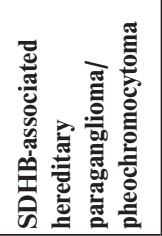 & 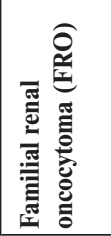 \\
\hline
\end{tabular}


is due to accumulation of genetic and epigenetic changes in the cells of ageing individuals and failing repair and defence mechanisms. However, this is not true for hereditary forms of RCC. Hereditary RCC is rather rare and specific. Hereditary forms of RCC typically occur at a younger age. More frequently, hereditary RCC is multifocal and bilateral. Most of the known forms of hereditary RCC are linked to syndromes (with the exception of balanced translocations of chromosome 3 ).

The study of hereditary RCC has led to identification of hereditary syndromes in RCC.

Pavlovich and Schmidt listed 7 hereditary syndromes associated with RCC, in 5 of which genes causing the syndromes had been revealed ${ }^{2}$. The presented article expands the list to 11 syndromes and more than 10 genes associated with the development of these syndromes.

Renal cell carcinoma is not a single disease but an entire collection of different types of cancer, each of which is caused by a different gene and has a different histology and clinical course. Each of the genes (VHL, MET, FLCN, TSC1, TSC2, FH and SDH) is, in a way or another, involved in pathways responding to metabolic stress or nutrient stimulation.

Mutations in each of these genes result in dysregulation of metabolic pathways involved in oxygen, iron, energy or nutrient sensing, suggesting that RCC is a disease of cell metabolism ${ }^{8}$.

Hereditary forms of RCC usually have a typical structure and occur at a much younger age as compared with sporadic forms. Since hereditary RCC is usually a tumour syndrome, besides renal manifestation, there are other extrarenal - manifestations of the syndrome. Frequently, extrarenal manifestations may prevail and RCC develops in only a small proportion of patients suffering from a particular syndrome.

Hereditary syndromes associated with increased or earlier development of RCC are summarized in (Table 2). Hereditary RCC occurs at a younger age whereas in the normal population, RCC is seen between the ages of 60 and 70. More frequently, hereditary RCC is multifocal and bilateral. Moreover, unlike sporadic RCC that is twice as frequent in males, the gender distribution is equal ${ }^{9,10}$.

If a hereditary type of tumour is suspected, tumour histology and possibly extrarenal symptoms may be helpful in the differential diagnosis to rule out sporadic forms ${ }^{11}$.

All the listed syndromes are autosomal dominant, with the exception of RCC associated with involvement of chromosome 3 (ref. $^{11}$ ).

\section{SYNDROMES ASSOCIATED WITH RCC}

\section{Von Hippel-Lindau (VHL) syndrome}

In VHL syndrome, an increased incidence of ccRCC is observed.

VHL syndrome results from a mutation in the VHL tumour suppressor gene. The disease is autosomal dominant and highly penetrant $\left(80-90 \%\right.$ penetrance $\left.{ }^{2}\right)$. Approximately $24-45 \%$ (ref. $^{12}$ ) patients with VHL syn- drome develop ccRCC, typically between 25 and 60 years (a mean of about 39 years $^{12}$ ). Histologically, the cases are almost exclusively ccRCC. The tumours are usually solid or cystic, very often multifocal and bilateral ${ }^{2,11,13,14}$.

The extrarenal manifestations of VHL syndrome include retinal and CNS haemangioblastomas, pheochromocytomas, pancreatic cysts and neuroendocrine tumours, endolymphatic sac tumours, and epididymal and broad ligament cystadenomas ${ }^{2,11,14}$.

The incidence of VHL syndrome is reported as between 1/35,000 (ref. ${ }^{14}$ ) and 1/36,000 (ref. ${ }^{15}$ ).

\section{Hereditary papillary renal carcinoma (HPRC)}

Families with HRPC syndrome suffer from type 1 papillary RCC. The syndrome is caused by mutation of the MET (mesenchymal-epithelial transition factor) proto-oncogene $e^{2,11,14}$. The mutation is typical for familial papillary RCC.

Apart from type 1 papillary carcinoma, neither other typical manifestations nor the exact incidence of this hereditary RCC are known. HPRC typically develops between the 5 th and 6 th decade of life. The disorder is highly penetrant. Persons affected by HPRC sndrome have a $90 \%$ (ref. $^{16,17}$ ) likelihood of developing RCC by the age of 80 years $^{8,18}$.

\section{Hereditary leiomyomatosis and renal cell carcinoma (HLRCC)}

Individuals affected by HLRCC syndrome are at increased risk of type 2 papillary RCC. This type is rarer but more aggressive ${ }^{18,19}$.

HLRCC syndrome is caused by mutations in the fumarate hydratase $(\mathrm{FH})$ gene on chromosome 1q42-43.

In addition to renal involvement, it is common for patients with HLRCC to have uterine leiomyomas, leiomyosarcomas and cutaneous leiomyomas $2,11,13,14,20$.

(Some families, however, are only affected by cutaneous and uterine leiomyomas, rarely with RCC. In such cases, the syndrome is called multiple cutaneous and uterine leiomyomatosis ${ }^{2}$ ).

HLRCC usually occurs at a young age (the youngest known case was at the age of 16 years ${ }^{13}$, with a median incidence at the age of 39 years $^{14}$ ).

\section{Birt-Hogg-Dubé (BHD) syndrome}

The gene mutated in Birt-Hogg-Dubé syndrome is FLCN, previously known as BHD. Mutations in the FLCN gene are found especially in hereditary forms of RCC (ref. ${ }^{9,21-24}$ ).

About 25-35\% (ref. ${ }^{13}$ ) of patients with BHD syndrome develop various types of renal tumours ${ }^{13,25-27}$.

Histologically, the tumours are hybrid chromophobe/ oncocytoma (50\%), chromophobe (34\%), ccRCC (9\%) and oncocytoma (5\%) (ref. $\left.{ }^{2}\right)$.

Various histological types of RCC may be present within a single family affected by BHD syndrome, in a single patient or even in the same kidney ${ }^{28,13}$.

Tumour lesions may be solitary or bilateral and multifocal. 
Members of families affected by BHD syndrome have a 7-fold increased risk of RCC as compared with the normal population ${ }^{26}$.

In addition to RCC, the BHD manifestations include cutaneous papules (fibrofolliculomas, most commonly on the head, neck and anterior trunk) in about $85 \%$ (ref. ${ }^{13}$ ) of BHD patients and lung cysts in more than $80 \%$ (ref..$^{13}$ ) of patients. About 25\% (ref. ${ }^{13}$ ) of patients have a history of spontaneous pneumothorax. Although some families were found to have a higher prevalence of colon cancer it is not known yet whether this may be considered a BHD syndrome manifestation ${ }^{28}$.

The prevalence of BHD syndrome is 1:200,000 (ref. ${ }^{28}$ ).

In BHD syndrome, RCC typically occurs around the age of 50 (ref. $^{14,24,28}$ ).

\section{Hyperparathyroidism-jaw tumour (HPT-JT)}

In some families, hereditary HPT-JT syndrome increases the prevalence of kidney neoplasms - nephroblastomas, hamartomas and Wilms' tumour and renal cysts $^{27,29,30}$.

Approximately 95\% $\left(\right.$ ref. $^{29}$ ) of persons with HPT-JT develop hyperparathyroidism, $5 \%$ (ref. $^{29}$ ) of patients develop parathyroid carcinoma and about half of the patients are known to have fibro-osseous mandibular and maxillary tumours.

HPT-JT is associated with mutations in the HRPT2 (hyperparathyroidism 2) tumour suppressor gene. Since only about 50 families have been reported so far, the exact incidence has not been determined ${ }^{30}$.

\section{Constitutional chromosome 3 translocation}

Balanced chromosome 3 translocations are a rare cause of ccRCC (OMIM 603046 and 144700) 31,32,14. A total of 13 different constitutional translocations involving chromosome 3 have been described, of which 7 are associated with familial kidney cancer and the remaining 6 were not found to run in families ${ }^{33,34}$.

The candidates are many genes on chromosome 3 (incl. FHIT, TRC8, DIRC1, DIRC2, DIRC3, HSBAP1, LSAMP, RASSF5, KCNIP4 and FBW7 (ref. ${ }^{33,34}$ ); SETD2 and JARID1C (ref. ${ }^{35}$ ); Rebouissou suggested that the impact of germline mutations HNF1B and HNF1A may predispose to RCC (ref. $\left.{ }^{36}\right)$ ).

At present, little is known about RCC caused by constitutional chromosomal translocations. The only clue is the presence of chromosome 3 translocation and multifocal and bilateral ccRCC.

The search for other genes responsible for hereditary forms of kidney cancer/renal cell carcinoma has not been completed. Several other genetic abnormalities will likely be associated with familial kidney cancer.

\section{Familial papillary thyroid cancer (FPTC)}

Persons affected by the syndrome have higher rates of papillary RCC and renal oncocytoma. In addition to tumours of the kidney, they develop papillary thyroid cancer and nodular thyroid disease. Of all cases of papillary thyroid cancer, only $5 \%$ (ref. $^{2}$ ) are of hereditary origin.
The FPTC phenotype has been linked to 1q21 (ref. ${ }^{37}$ ), indicating a new RCC-associated gene could be responsible for this syndrome ${ }^{14}$.

\section{Familial RCC of as yet unknown genetic cause}

Familial ccRCC is defined as the development of ccRCC in two or more members of the same family, in whom VHL disease and constitutional chromosome 3 translocation have been ruled out ${ }^{38,39,7,14}$. This type of tumour is associated with a very low frequency (over 70 families have been reported). In those families, first-degree relatives have a 2-3-fold increased risk of RCC than the normal population ${ }^{40}$. As the cause remains unknown, the multigenetic mechanism of inheritance is assumed ${ }^{2}$.

\section{Tuberous sclerosis (TS)}

This hereditary syndrome is associated with mutations in the TSC1 and TSC2 genes $^{41,42}$.

As much as $70 \%$ (ref. $^{14}$ ) of TS cases are caused by spontaneous germline mutation and only $30 \%\left(\right.$ ref. $^{14}$ ) are hereditary. (The hereditary form is characterized by almost complete penetrance but variable expressivity.)

Renal lesions are seen in 50-80\% (ref. ${ }^{14}$ ) of TS patients (angiomyolipomas, cysts, oncocytomas, RCC). Renal angiolipomas may be life-threatening if bleeding occurs ${ }^{11}$.

Between $1 \%$ and $4 \%\left(\right.$ ref. $\left.^{43,44}\right)$ of patients with TS syndrome develop RCC.

Although the incidence is consistent with sporadic forms of RCC, they develop at a young age - 28 years of age on average ${ }^{45}$. Most frequent is ccRCC but chromophobe RCC, papillary RCC and oncocytomas were also reported $^{46}$.

A total of $90 \%$ (ref. $^{11}$ ) of TS patients suffer from epilepsy. Only $30 \%$ (ref. $^{11}$ ) of cases have the classical triad of epilepsy, mental retardation and sebaceous adenoma. Skin manifestations include hypomelanotic macules, facial angiofibromas, shagreen patches and fibrous plaques. In the mouth, gingival fibromas may be found. Other potential extrarenal manifestations are periventricular hamartomas, cardiac rhabdomyomas and retinal hamartomas. As many as $75 \%$ (ref. ${ }^{11}$ ) of patients are found to have renal asymptomatic angiomyolipomas.

\section{Hereditary paraganglioma/pheochromocytoma}

Originally, two families with hereditary paragangliomas were found to have a higher prevalence of ccRCC. In those persons, three out of four genes encoding succinate dehydrogenase, a Krebs cycle enzyme, were mutated (SDHB, SDHC, SDHD) (ref. $\left.{ }^{47}\right)$. Later research revealed bilateral, multifocal ccRCC or chromophobe RCC with a very early onset ${ }^{48}$.

Other - extrarenal - tumours include paragangliomas and pheochromocytomas. The patients are diagnosed with kidney cancer before the age of 30 . As the disease is rare, the prevalence is as yet unknown.

\section{Familial renal oncocytoma (FRO)}

The syndrome is usually associated with solitary, multifocal and bilateral oncocytomas. As of now, FRO 
syndrome is only known to be autosomal dominant but the particular gene has not been identified. Potential overlap with BHD is being studied ${ }^{49}$. On average, persons with FRO develop kidney cancer at the age of 55.8 years $^{50}$. Apart from kidney cancer, no other manifestations are known.

Due to the low frequency (only about 20 cases are known), the exact prevalence of the syndrome has not been determined.

\section{DISCUSSION}

The importance of the study of hereditary forms of $\mathrm{RCC}$ is in identifying pathways involved in the particular type of tumours. Subsequently, the pathways are also studied in sporadic forms of the tumour. The knowledge of the development and mechanism of involvement of genetic pathways leads us to the metabolic effect resulting from the genetic disorder and gives us a chance to distinguish various forms of the same histological type of cancer. As a result, the so-called tailored therapy may be applied in each individual patient.

The exact mechanism of the development of hereditary RCC is still not completely known. The key steps are activation of the cell proliferation cascade and prevention of apoptosis ${ }^{2,21,51}$. Impaired regulation of proliferation and angiogenesis are two main components of carcinogenesis in the kidneys ${ }^{21}$.

The findings may also be applied in prevention of kidney cancer in families affected by any of the syndromes. The question is how to tell that an individual has a hereditary form of RCC.

A hereditary form of RCC should be suspected if: 1) the patient has a personal or family history of RCC, 2) there is bilateral or/multifocal RCC,

3 ) there is early-onset RCC (under 50 years of age ${ }^{2,52,53}$ ). Additionally, RCC should be suspected if the patient or his/her relatives has any of extrarenal manifestations typical for certain forms of syndromes, such as fibrofolliculomas or pneumothorax ${ }^{14}$.

According to Axwijk et al., screening should be recommended to ${ }^{11}$ :

1) patients with a mutation in one of the mentioned genes, associated with a RCC syndrome,

2) patients and first-degree relatives from a family with a suspected RCC syndrome, which could not be confirmed by genetic analysis,

3) patients and first-degree relatives in a family with two or more first- or second-degree relatives with RCC,

4) individuals with RCC before the age of 50 and their first-degree relatives.

For diagnosis and secondary prevention, ultrasound and CT are the examination of choice in persons with kidney disease manifestations. At present, however, these preventive (screening) measures can mostly be applied in persons with an increased risk of developing this serious condition.

\section{CONCLUSION}

Although hereditary forms of RCC are relatively rare, their study is beneficial in many ways. In individuals at a higher risk of a hereditary syndrome, the knowledge of hereditary forms may help to significantly decrease the impact of the hereditary disease. In the general population, knowledge acquired by the study of hereditary forms of RCC may in the future contribute to both diagnosis and treatment of sporadic tumours.

The latest genetic tests are increasingly used for identification of patients with a particular genetic abnormality potentially underlying RCC. However, due to financial and organizational reasons, screening of increasing numbers of patients at risk may be a serious economic problem in the future. Therefore, it is essential to identify various strategies according to the severity of a risk increase in a particular individual.

\section{ABBREVIATIONS}

BHD, Birt-Hogg-Dubé; ccRCC, Clear cell RCC; c-Met (MET), Protooncogene coding hepatocyte growth factor receptor (HGFR); c-MYC, Protooncogene; CNS, Central nervous system; CT, Computer tomography; DIRC1, Disrupted in renal carcinoma 1; DIRC2, Disrupted in renal carcinoma 2; DIRC3, Disrupted in renal carcinoma 3; FBW7, F-box and WD repeat domain containing 7; FH, Fumarate hydratase; FHIT, Gene coding fragile histidine triad protein; FLCN, Folliculin, previously known as BHD gene; FPTC, Familial papillary thyroid cancer; FRO, Familial renal oncocytoma; HGF, Hepatocyte growth factor; HIF, Hypoxia inducible factor; HLRCC, Hereditary leiomyomatosis and renal cell carcinoma; HNF1A, HNF1 homeobox A; HNF1B, HNF1 homeobox B; HPRC, Hereditary papillary renal carcinoma; HPT-JT, Hyperparathyroidism-jaw tumour; HRPT2, Hyperparathyroidism 2, tumour suppressor gene; HSPBAP1, Heat-shock 27-kD protein-associated protein 1; IARC, The International Agency for Research on Cancer; JARID1C, Jumonji, AT rich interactive domain $1 \mathrm{C}$ (known also like KDM5C - lysine (K)-specific demethylase 5C); KCNIP4, Kv channel interacting protein 4; LSAMP, Gene coding limbic system-associated membrane protein; MET, Mesenchymal-epithelial transition factor, proto-oncogene; MRI, Magnetic resonance imaging; mTOR, Mammalian target of rapamycin; RASSF5, Ras association (RalGDS/AF-6) domain family member 5; RCC, Renal cell carcinoma; SDH, Succinate dehydrogenase, a Krebs cycle enzyme; SDHB, SDHC, SDHD, genes encoding succinate dehydrogenase subunits; SETD2, SET domain containing ; TRC8, Translocation in renal carcinoma, chromosome 8 gene; TS, Tuberous sclerosis; TSC1, Gene coding tuberous sclerosis protein 1; 
TSC2, Gene coding tuberous sclerosis protein 2; VHL, Von Hippel-Lindau.

\section{ACKNOWLEDGEMENTS}

Supported by the Czech Ministry of Health project NS10290 Epidemiologic Study of Genetic and Behavioural Risk factors in Kidney Cancer.

The authors have no financial relationship(s) with commercial interests to disclose.

\section{REFERENCES}

1. Ferlay J, Shin HR, Bray F, Forman D, Mathers C, Parkin DM GLOBOCAN 2008, Cancer Incidence and Mortality Worldwide: IARC CancerBase No. 10 [Internet]. Lyon, France: International Agency for Research on Cancer; 2010. Available from: http://globocan.iarc.fr

2. Pavlovich CP, Schmidt LS. Searching for the hereditary causes of renal-cell carcinoma. Nat Rev Cancer 2004;4(5):381-93.

3. Nickerson ML, Jaeger E, Shi Y, Durocher JA, Mahurkar S, Zaridze D, Matveev V, Janout V, Kollarova H, Bencko V, Navratilova M, Szeszenia-Dabrowska N, Mates D, Mukeria A, Holcatova I, Schmidt LS, Toro JR, Karami S, Hung R, Gerard GF, Linehan WM, Merino M, Zbar B, Boffetta P, Brennan P, Rothman N, Chow WH, Waldman FM, Moore LE. Improved identification of von Hippel-Lindau gene alterations in clear cell renal tumors. Clin Cancer Res 2008;14(15):4726-34.

4. Linehan WM, Walther MM, Zbar B. The genetic basis of cancer of the kidney. J Urol 2003;170:2163-72.

5. Valladares-Ayerbes M, Aparicio Gallego G, Díaz Prado S, Jiménez Fonseca P, García Campelo R, Antón Aparicio LM. Origin of renal cell carcinomas. Clin Transl Oncol 2008;10(11):697-712.

6. Banumathy G, Cairns P. Signaling pathways in renal cell carcinoma. Cancer Biol Ther 2010;10(7):658-64

7. Zbar B, Klausner R, Linehan WM. Studying cancer families to identify kidney cancer genes. Annu Rev Med 2003;54:217-33.

8. Linehan WM, Srinivasan R, Schmidt LS. The genetic basis of kidney cancer: a metabolic disease. Nat Rev Urol 2010;7(5):277-85.

9. Toro JR, Wei MH, Glenn GM, Weinreich M, Toure O, Vocke C, Turner M, Choyke P, Merino MJ, Pinto PA, Steinberg SM, Schmidt LS, Linehan WM. BHD mutations, clinical and molecular genetic investigations of Birt-Hogg-Dubé syndrome: a new series of 50 families and a review of published reports. J Med Genet 2008;45(6):321-31.

10. Alam NA, Olpin S, Leigh IM. Fumarate hydratase mutations and predisposition to cutaneous leiomyomas, uterine leiomyomas and renal cancer. Br J Dermatol 2005;153(1):11-7.

11. Axwijk PH, Kluijt I, de Jong D, Gille H, Teertstra J, Horenblas S. Hereditary causes of kidney tumours. Eur J Clin Invest 2010;40(5):433-9.

12. Lonser RR, Glenn GM, Walther M, Chew EY, Libutti SK Linehan WM, Oldfield EH. von Hippel-Lindau disease. Lancet 2003;361(9374):2059-67.

13. Pfaffenroth EC, Linehan WM. Genetic basis for kidney cancer opportunity for disease-specific approaches to therapy. Expert Opin Biol Ther 2008;8(6):779-90.

14. Verine J, Pluvinage A, Bousquet G, Lehmann-Che J, de Bazelaire C, Soufir N, Mongiat-Artus P. Hereditary Renal Cancer Syndromes: An Update of a Systematic Review. Eur Urol 2010.

15. Maher ER, Iselius L, Yates JR, Littler M, Benjamin C, Harris R, Sampson J, Williams A, Ferguson-Smith MA, Morton N. Von Hippel-Lindau disease: a genetic study. J Med Genet 1991;28(7):443-7.

16. Linehan MW, Bratslavsky G, Pinto PA, Schmidt LS, Neckers L, Bottaro D, Srinivasan R. Molecular Diagnosis and Therapy of Kidney Cancer. Annu Rev Med 2010;61:329-343.
17. Schmidt L, Junker K, Weirich G, Glenn G, Choyke P, Lubensky I, Zhuang Z, Jeffers M, Vande Woude G, Neumann H, Walther M,Linehan WM, Zbar B. Two North American families with hereditary papillary renal carcinoma and identical novel mutations in the MET proto-oncogene. Cancer Res 1998;58:1719-22.

18. Launonen V, Vierimaa O, Kiuru M, Isola J, Roth S, Pukkala E, Sistonen P, Herva R, Aaltonen LA. Inherited susceptibility to uterine leiomyomas and renal cell cancer. Proc Natl Acad Sci U S A 2001;98(6):3387-92.

19. Kiuru M, Launonen V, Hietala M, Aittomäki K, Vierimaa O, Salovaara R, Arola J, Pukkala E, Sistonen P, Herva R, Aaltonen LA. Familial cutaneous leiomyomatosis is a two-hit condition associated with renal cell cancer of characteristic histopathology. Am J Pathol 2001;159(3):825-9.

20. Rosner I, Bratslavsky G, Pinto PA, Linehan WM. The clinical implications of the genetics of renal cell carcinoma. Urol Oncol 2009;27(2):131-6.

21. Baba M, Hong SB, Sharma N, Warren MB, Nickerson ML, Iwamatsu A, Esposito D, Gillette WK, Hopkins RF 3rd, Hartley JL, Furihata M, Oishi S, Zhen W, Burke TR Jr, Linehan WM, Schmidt LS, Zbar B. Folliculin encoded by the BHD gene interacts with a binding protein, FNIP1, and AMPK, and is involved in AMPK and mTOR signaling. Proc Natl Acad Sci U S A 2006;103(42):15552-7.

22. Kluger N, Giraud S, Coupier I, Avril MF, Dereure O, Guillot B, Richard S, Bessis D. Birt-Hogg-Dubé syndrome: clinical and genetic studies of 10 French families. Br J Dermatol 2010;162(3):527-37.

23. Hartman TR, Nicolas E, Klein-Szanto A, Al-Saleem T, Cash TP, Simon MC, Henske EP. The role of the Birt-Hogg-Dubé protein in mTOR activation and renal tumorigenesis. Oncogene 2009;28(13):1594-604.

24. Coleman JA, Russo P. Hereditary and familial kidney cancer. Curr Opin Urol 2009;19(5):478-85.

25. Toro JR, Glenn G, Duray P, Darling T, Weirich G, Zbar B, Linehan M, Turner ML. Birt-Hogg-Dubé syndrome: a novel marker of kidney neoplasia. Arch Dermatol 1999;135(10):1195-202.

26. Zbar B, Alvord WG, Glenn G, Turner M, Pavlovich CP, Schmidt L, Walther M, Choyke P, Weirich G, Hewitt SM, Duray P, Gabril F, Greenberg C, Merino MJ, Toro J, Linehan WM. Risk of renal and colonic neoplasms and spontaneous pneumothorax in the Birt-Hogg-Dubé syndrome. Cancer Epidemiol Biomarkers Prev 2002;11(4):393-400.

27. Pavlovich CP, Walther MM, Eyler RA, Hewitt SM, Zbar B, Linehan WM, Merino MJ. Renal tumors in the Birt-Hogg-Dubé syndrome. Am J Surg Pathol 2002;26(12):1542-52.

28. Toschi B, Genuardi M . Birt-Hogg-Dubé syndrome (BHD). Atlas Genet Cytogenet Oncol Haematol. February 2006. Available from: http://AtlasGeneticsOncology.org/Kprones/ BirtHoggDubeID10091.html

29. Hobbs MR . Hyperparathyroidism-Jaw tumor syndrome (HPTJT). Atlas Genet Cytogenet Oncol Haematol. May 1999. Available from: http://AtlasGeneticsOncology.org/Kprones/HyperparJawID10052.html

30. Newey PJ, Bowl MR, Thakker RV. Parafibromin-functional insights. J Intern Med 2009;266(1):84-98.

31. Victor A. McKusick, P. A. (18. 9 1998). Ring finger protein 139; RNF139. Načteno z OMIM Online Mendelian Inheritance in Man. Available from: http://www.ncbi.nlm.nih.gov/omim/603046

32. Victor A. McKusick, M. J. (6. 4 1986). Renal cell carcinoma, nonpapillary; RCC. Načteno z OMIM Online Mendelian Inheritance in Man. Available from: http://www.ncbi.nlm.nih.gov/omim/144700

33. Woodward ER, Skytte AB, Cruger DG, Maher ER. Populationbased survey of cancer risks in chromosome 3 translocation carriers. Genes Chromosomes Cancer 2010;49(1):52-8.

34. Kuiper RP, Vreede L, Venkatachalam R, Ricketts C, Kamping E, Verwiel E, et al. The tumor suppressor gene FBXW7 is disrupted by a constitutional $\mathrm{t}(3 ; 4)(\mathrm{q} 21 ; \mathrm{q} 31)$ in a patient with renal cell cancer. Cancer Genet Cytogenet 2009;195(2):105-11

35. Dalgliesh GL, Furge K, Greenman C, Chen L, Bignell G, Butler A, Davies H, Edkins S, Hardy C, Latimer C, Teague J, Andrews J, Barthorpe S, Beare D, Buck G, Campbell PJ, Forbes S, Jia M, Jones D, Knott H, Kok CY, Lau KW, Leroy C, Lin ML, McBride 
DJ, Maddison M, Maguire S, McLay K, Menzies A, Mironenko T, Mulderrig L, Mudie L, O’Meara S, Pleasance E, Rajasingham A, Shepherd R, Smith R, Stebbings L, Stephens P, Tang G, Tarpey PS, Turrell K, Dykema KJ, Khoo SK, Petillo D, Wondergem B, Anema J, Kahnoski RJ, Teh BT, Stratton MR, Futreal PA. Systematic sequencing of renal carcinoma reveals inactivation of histone modifying genes. Nature 2010;463(7279):360-3.

36. Rebouissou S, Vasiliu V, Thomas C, Bellanné-Chantelot C, Bui H, Chrétien Y, Timsit J, Rosty C, Laurent-Puig P, Chauveau D, Zucman-Rossi J. Germline hepatocyte nuclear factor 1alpha and 1 beta mutations in renal cell carcinomas. Hum Mol Genet 2005;14(5):603-14.

37. Malchoff CD, Sarfarazi M, Tendler B, Forouhar F, Whalen G, Joshi V, Arnold A, Malchoff DM. Papillary thyroid carcinoma associated with papillary renal neoplasia: genetic linkage analysis of a distinct heritable tumor syndrome. J Clin Endocrinol Metab 2000;85(5):1758-64.

38. Zbar B. Inherited epithelial tumors of the kidney: old and new diseases. Semin Cancer Biol 2000;10(4):313-8.

39. Woodward ER, Ricketts C, Killick P, Gad S, Morris MR, Kavalier F, Hodgson SV, Giraud S, Bressac-de Paillerets B, Chapman C, Escudier B, Latif F, Richard S, Maher ER. Familial non-VHL clear cell (conventional) renal cell carcinoma: clinical features, segregation analysis, and mutation analysis of FLCN. Clin Cancer Res 2008;14(18):5925-30.

40. Gudbjartsson T, Jónasdóttir TJ, Thoroddsen A, Einarsson GV, Jónsdóttir GM, Kristjánsson K, Hardarson S, Magnússon K, Gulcher J, Stefánsson K, Amundadóttir LT. A population-based familial aggregation analysis indicates genetic contribution in a majority of renal cell carcinomas. Int J Cancer 2002;100(4):476-9.

41. McKusick, V. A. (10. 2 1992). TSC2 gene; TSC2. Available from: http://www.ncbi.nlm.nih.gov/omim/191092

42. McKusick, V. A. (6.2 1986). Tuberous sclerosis 1; TSC1. Available from: http://www.ncbi.nlm.nih.gov/omim/191100

43. Coleman JA. Familial and hereditary renal cancer syndromes. Urol Clin North Am 2008;35(4):563-72.

44. Linehan WM, Pinto PA, Bratslavsky G, Pfaffenroth E, Merino M, Vocke CD, Toro JR, Bottaro D, Neckers L, Schmidt LS, Srinivasan R. Hereditary kidney cancer: unique opportunity for disease-based therapy. Cancer 2009;115(10 Suppl):2252-61.

45. Yates JR. Tuberous sclerosis. Eur J Hum Genet 2006;14(10):106573.

46. Crino PB, Nathanson KL, Henske EP. The tuberous sclerosis complex. N Engl J Med 2006;355(13):1345-56.

47. Vanharanta S, Buchta M, McWhinney SR, Virta SK, Peçzkowska M, Morrison CD, Lehtonen R, Januszewicz A, Järvinen H, Juhola M, Mecklin JP, Pukkala E, Herva R, Kiuru M, Nupponen NN, Aaltonen LA, Neumann HP, Eng C. Early-onset renal cell carcinoma as a novel extraparaganglial component of SDHB-associated heritable paraganglioma. Am J Hum Genet 2004;74(1):153-9.
48. Ricketts C, Woodward ER, Killick P, Morris MR, Astuti D, Latif F, Maher ER. Germline SDHB mutations and familial renal cell carcinoma. J Natl Cancer Inst 2008;100(17):1260-2.

49. Toro JR, Glenn G, Duray P, Darling T, Weirich G, Zbar B, Linehan M, Turner ML. Birt-Hogg-Dubé syndrome: a novel marker of kidney neoplasia. Arch Dermatol 1999;135(10):1195-202.

50. Weirich G, Glenn G, Junker K, Merino M, Störkel S, Lubensky I, Choyke P, Pack S, Amin M, Walther MM, Linehan WM, Zbar B. Familial renal oncocytoma: clinicopathological study of 5 families. J Urol 1998;160(2):335-40.

51. Favier J, Brière JJ, Strompf L, Amar L, Filali M, Jeunemaitre X, Rustin P, Gimenez-Roqueplo AP; PGL.NET Network. Hereditary paraganglioma/pheochromocytoma and inherited succinate dehydrogenase deficiency. Horm Res 2005;63(4):171-9.

52. Richard S, Lidereau R, Giraud S. The growing family of hereditary renal cell carcinoma. Nephrol Dial Transplant 2004;19(12):2954-8.

53. Cohen HT, McGovern FJ. Renal-cell carcinoma. N Engl J Med 2005;353(23):2477-90.

54. Toro JR, Nickerson ML, Wei MH, Warren MB, Glenn GM, Turner ML, Stewart L, Duray P, Tourre O, Sharma N, Choyke P, Stratton P,Merino M, Walther MM, Linehan WM, Schmidt LS, Zbar B. Mutations in the fumarate hydratase gene cause hereditary leiomyomatosis and renal cell cancer in families in North America. Am J Hum Genet 2003;73(1):95-106.

55. Grubb RL 3rd, Franks ME, Toro J, Middelton L, Choyke L, Fowler S, Torres-Cabala C, Glenn GM, Choyke P, Merino MJ, Zbar B, Pinto PA, Srinivasan R, Coleman JA, Linehan WM. Hereditary leiomyomatosis and renal cell cancer: a syndrome associated with an aggressive form of inherited renal cancer. J Urol 2007;177(6):20749; discussion 2079-80.

56. Sharretts JM, Simonds WF. Clinical and molecular genetics of parathyroid neoplasms. Best Pract Res Clin Endocrinol Metab 2010;24(3):491-502.

57. Carpten JD, Robbins CM, Villablanca A, Forsberg L, Presciuttini S, Bailey-Wilson J, Simonds WF, Gillanders EM, Kennedy AM, Chen JD, Agarwal SK, Sood R, Jones MP, Moses TY, Haven C, Petillo D, Leotlela PD, Harding B, Cameron D, Pannett AA, Höög A, Heath H 3rd, James-Newton LA, Robinson B, Zarbo RJ, Cavaco BM, Wassif W, Perrier ND, Rosen IB, Kristoffersson U, Turnpenny PD, Farnebo LO, Besser GM, Jackson CE, Morreau H, Trent JM, Thakker RV, Marx SJ, Teh BT, Larsson C, Hobbs MR. HRPT2, encoding parafibromin, is mutated in hyperparathyroidism-jaw tumor syndrome. Nat Genet 2002;32(4):676-80.

58. Sampson JR, Scahill SJ, Stephenson JB, Mann L, Connor JM Genetic aspects of tuberous sclerosis in the west of Scotland. J Med Genet 1989;26(1):28-31.

59. Gimenez-Roqueplo AP . Hereditary paraganglioma (PGL). Atlas Genet Cytogenet Oncol Haematol. February 2002. Available from: http://AtlasGeneticsOncology.org/Kprones/ HeredParagangID10043.html 